\title{
The Effectiveness of Chitosan- Pinus merkusii Extract Nanoparticle as Antioxidant and Anti-caspase 3 in against Lead Acetate Toxicity on the Lung of Wistar Rat
}

\author{
Sri Agus Sudjarwo ${ }^{1, \star}$, Giftania Wardani ${ }^{2}$, Koerniasari Eraiko ${ }^{3}$, Koerniasari ${ }^{4}$, Ernawati ${ }^{5}$ \\ ${ }^{1}$ Department of Pharmacology, Faculty of Veterinary Medicine, Airlangga University, Surabaya, INDONESIA. \\ ${ }^{2}$ Department of Pharmacy Biology, Faculty of Pharmacy, Hang Tuah University, Surabaya, INDONESIA. \\ ${ }^{3}$ Department of Conservative Dentistry, Faculty of Dentistry, Airlangga University, Surabaya, INDONESIA. \\ ${ }^{4}$ Study Program of Environmental Health, Polytechnic of Health, Surabaya, INDONESIA. \\ ${ }^{5}$ Department of P3M, STIKES Delima Persada, Gresik, INDONESIA
}

\begin{abstract}
Background: The antioxidants can be used for protective in oxidative stress that is one of the important mechanisms of lead acetate-induced lung toxicity. Objective: The current study was carried out to evaluate the effectiveness of Chitosan- Pinus merkusii extract nanoparticle as antioxidant and anti-caspase 3 in against lead acetate-induced lung toxicity on wistar rats. Methods: Chitosan- Pinus merkusii nanoparticle were characterized by Dynamic Light Scattering (DLS) and Scanning Electron Microscope (SEM). The male rats were divided into control group (Rats were given with distilled water); lead acetate group (Rats were injected with lead acetate $20 \mathrm{mg} / \mathrm{kg} \mathrm{BW}$ i.p) and the treatment group (Rats were given the Chitosan- Pinus merkusii nanoparticle 150 $\mathrm{mg} ; 300 \mathrm{mg} ; 600 \mathrm{mg} / \mathrm{kg}$ BW orally and were injected with lead acetate $20 \mathrm{mg} / \mathrm{kg} \mathrm{BW}$ ). The lung tissues were collected to evaluate the malondialdehyde (MDA), Superoxide Dismutase (SOD), Glutathione Peroxidase (GPx), histological evaluations of lung damage and immunohistochemical of the expression of caspase 3. Results: The results of DLS showed that the size of Chitosan- Pinus merkusii nanoparticle was $430.5 \pm 24.8 \mathrm{~nm}$. SEM images of the Chitosan- Pinus merkusii nanoparticles showed an irregular shape and the morphology surface showed the rough surface. Administration of lead acetate resulted in a significant increase in MDA level, caspase 3 expression and decrease in level of SOD and GPx. Treatment with the Chitosan- Pinus merkusii nanoparticle 600 $\mathrm{mg} / \mathrm{kg}$ BW but not 150 and $300 \mathrm{mg} / \mathrm{kg}$ BW significantly decreased the MDA levels, caspase 3 expression and also increase in level of SOD and GPx were compared with lead acetate group. The lead acetate-induced thickened the alveolar septa and loss of the normal structure of lung cells (Necrosis), whereas treated with Chitosan-Pinus merkusii nanoparticle inhibited lung cell necrosis. Conclusion: From the results of this study demonstrated that Chitosan- Pinus merkusii nanoparticle could be a potent against lead acetate- induced lung toxicity, through increasing antioxidant and inhibiting caspase 3 expression.
\end{abstract}

Key words: Chitosan- Pinus merkusii nanoparticle, Antioxidant, Caspase 3, Lead acetate, Lung toxicity.
Submission Date: 20-10-2018; Revision Date: 28-12-2018; Accepted Date: 20-03-2019

DOI: 10.5530/ijper.53.2s.58 Correspondence: Prof. Sri Agus Sudjarwo, Department of Pharmacology, Faculty of Veterinary Medicine, Airlangga University, Surabaya, INDONESIA Phone: +62-31-5992785 E-mail: ags158@yahoo.com

\section{INTRODUCTION}

Lead is a highly toxic metal whose widespread use has caused extensive environmental pollution and health problems in human and animal. ${ }^{1,2}$ Lead acetate is one of a toxic heavy metal which induced damage in most of the body organs as kidney, ${ }^{3}$ testis, ${ }^{4}$ liver, ${ }^{5}$ heart ${ }^{6}$ and lung. ${ }^{7}$ The oxidative stress is an important mechanisms of lead

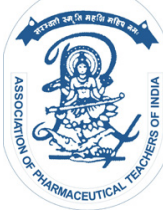

www.ijper.org 
acetate-induced lung cell damages via Reactive oxygen species (ROS) generation. ${ }^{7}$ Oxidative stress focuses the attention of worldwide researchers for its damaging effects on the body and also responsible for the death of a cell. Oxidative stress can occur when there is an imbalance between the generation of ROS and the scavenging capacity of antioxidants in the lung cells. It has been reported that lead-induced overproduction of Reactive oxygen species (ROS) or free radicals such as superoxide ion $\left(\mathrm{O}_{2}^{-}\right)$, Hydroxyl radical $\left(\mathrm{OH}^{-}\right)$and Nitric oxide (NO) and consequently enhance lipid peroxidation, impairment of antioxidant enzymes activities, such as superoxide dismutase (SOD), Catalase (CAT) and Glutathione peroxidase (GPx). ${ }^{8,9}$ In addition, free radicals are highly reactive to membrane lipids, protein, DNA and to be the major contributing factors to stress injuries and to cause rapid lung cell damage. ${ }^{5}$ Several experimental studies have reported of lead-induced apoptosis in rat tissue including testis, fibroblasts, liver and lung. ${ }^{10,11} \mathrm{Xu}$ et al. (2006) have shown that lead elicits DNA damage and apoptosis in a cell, accompanied by an increase in $\mathrm{Bax} / \mathrm{BCl} 2$ ratio and caspase 3 activity. ${ }^{12}$

It was reported that Malondialdehyde (MDA) is secondary products of lipid peroxidation, may be used as a biomarker of lung damage. The increase in MDA levels suggests enhanced lipid peroxidation leading to lung cell damage and decreased the activity of antioxidant defense mechanisms to prevent the formation of excessive free radicals. ${ }^{5,8}$

Studies have revealed that antioxidants possess the ability of both preventing and curing the damage caused by the toxic effects of lead that causes the generation of free radicals in the body. The natural product antioxidants have been reported to provide protection against lead-induced oxidative stress and emerged as a potential therapeutic to prevent free radical generated damage in the body. The natural product can be a good alternative as the antioxidant, because of their low costs, availability and lack of undesirable side effects. ${ }^{13}$

This study has been focused on natural products of Chitosan- Pinus merkusii having antioxidant properties for protective in reducing free radical-induced lung cell damage. It has been demonstrated that Pinus plant were due to the phytochemicals possessed, including alkaloids, polyphenols, flavonoids, lignans, triterpenes, sterols, glycosides, triterpenoids and saponins. ${ }^{14,15}$ Some researcher has stated that Pinus plant showed stronger effects for antioxidant (Free radical scavengers), antibacterial agents, anticancer, anti-inflammatory, immunestimulating, antiviral and estrogenic activities. ${ }^{15,16}$ Recent research activities have shown that Pinus plant is an important source of pycnogenol that contains pro- anthocyanidins (Procyanidins). ${ }^{17,18}$ Proanthocyanidins are potent, antioxidant (Free radical scavengers), antibacterial agents, exhibit vasodilatory, anticancer, antiinflammatory, immune-stimulating, antidiabetes and anti-atherosclerosis. ${ }^{19-21}$

In recent years, synthesis of natural product nanoparticles is an interesting issue of the nanoscience and nanobiotechnology. The natural product nanoparticle has the opportunities to prevent and treat diseases in both human and animal. Nanoparticles vary in size but are generally ranging from 100 to $800 \mathrm{~nm}$. Nanoparticlebased natural product delivery systems offer enhanced drug stability, treatment efficacy and penetration power compared to a pure natural product. ${ }^{22,23}$ Chitosan is one of natural product which exhibits adhesiveness, biocompatibility, biodegradability and is widely used in biomedical and pharmaceutical applications. ${ }^{24,25}$ Chitosan nanoparticles has been studied extensively by researchers for their controlled drug release properties and are used for both invitro and invivo applications. ${ }^{26,27}$ Its also non-toxic and have many biological activities such as antibacterial, antioxidant, antihyperlipidemic, anti-diabetic, anti-HIV, anti-inflammatory, drug delivery and immunostimulant, make it an ideal delivery agent for applications in medicine. ${ }^{27-29}$ The objective of the present study was carried out to evaluate the antioxidant and anti-caspase 3 activity of Chitosan- Pinus merkusii extract nanoparticle in against lead acetate-induced lung toxicity in wistar albino rats.

\section{MATERIALS AND METHODS}

\section{Preparation of Chitosan- Pinus merkusii Extract Nanoparticles}

The chitosan- Pinus merkusii extract nanoparticle was prepared according to the procedure first reported by based on the ionic gelation of chitosan- Pinus merkusii extract with Sodium Tripolyphosphate (TPP) anions. ${ }^{30,31}$ Briefly, concentrations of chitosan solutions $(0.2 \%$ $\mathrm{w} / \mathrm{v}$ ) were prepared in $0.1 \% \mathrm{v} / \mathrm{v}$ glacial acetic acid and filtered. The TPP solution $(0.1 \% \mathrm{w} / \mathrm{v})$ was prepared in deionized water. Pinus merkusii extract $0.4 \% \mathrm{w} / \mathrm{v}$ in ethanol $70 \%$ was added to chitosan solution $(0.2 \% \mathrm{w} / \mathrm{v})$ under constant stirring. The mixture was then sonicated for $5 \mathrm{~min}$ and TPP solution was added dropwise under constant stirring. The ratio of chitosan: TPP solution was maintained at 2:1 throughout the experiment. The supernatant obtained was subjected to ultracentrifugation at $25000 \mathrm{rpm}$ for $20 \mathrm{~min}$ to sediment the chitosan-propolis conjugated nanoparticles, which were then subjected to further characterization. 


\section{Characterization of nanoparticles by Scanning Electron Microscopy and Dynamic Light Scattering}

The surface morphological features such as particle size, shape and topography of the Chitosan-Pinus merkusii extract nanoparticle were observed using SEM.

Dynamic light scattering was done using Malvern Instruments version 2.2. The average particle size of the Chitosan- Pinus merkusii extract nanoparticle was determined.

\section{Experimental Animal}

Male Wistar rat weighing approximately 200-250 g (2.5-3 months) were obtained from Gadjah Mada University, Yogyakarta, Indonesia for experimental purpose. They were housed in plastic cages in an air-conditioned room with a temperature maintained at $26 \pm 2^{\circ} \mathrm{C}$ and $12 \mathrm{~h}$ alternates' light and dark cycles. The rats were given ad libitum with tap water and fed with standard commercial rat chow. This study was reviewed by the Ethical Clearance Committee for preclinical research, Institute of Tropical Disease, Airlangga University and obtained ethical clearance under No.178/ITD/1/2018.

\section{Experimental Design}

The sample used 50 male rats were divided into 5 groups: control group (Rats were given daily with distilled water); Lead acetate group (Rats were injected with lead acetate solution, i.p., at a dose of $20 \mathrm{mg} / \mathrm{kg} \mathrm{BW}$ for the 7 consecutive days and the treatment group (Rats were given the Chitosan- Pinus merkusii extract nanoparticle $150 \mathrm{mg} ; 300 \mathrm{mg} ; 600 \mathrm{mg} / \mathrm{kg} \mathrm{BW}$ orally once in a day for 11 days and on $4^{\text {th }}$ day, were injected with lead acetate solution, i.p., at a dose of $20 \mathrm{mg} / \mathrm{kg} \mathrm{BW}$ one $\mathrm{hr}$ after the Chitosan- Pinus merkusii extract nanoparticle). On day 11, the rats were sacrificed and lung tissues were homogenized in ice-cold $50 \mathrm{mM}$ sodium phosphate buffer ( $\mathrm{pH}$ 7.4) containing $0.1 \mathrm{mM}$ ethylenediamine tetraacetic acid (EDTA). The supernatant was separated by centrifugation at $1000 \mathrm{~g}$ for $20 \mathrm{~min}$ at $4^{\circ} \mathrm{C}$. The supernatant was used for the analyzes of MDA and antioxidant enzymes (SOD and GPx). The lung was also fixed in a $10 \%$ neutral buffered formalin solution for immunohistochemical evaluation of the expression of caspase 3 and histopathological evaluation of the lung damage.

\section{Measurement of MDA}

MDA was determined in the supernatant of homogenate lung tissue by the thiobarbituric acid (TBA) method which estimates the MDA formation. The concentration of MDA was measured at $532 \mathrm{~nm}$ and calculated by the absorbance coefficient of MDA-TBA complex. ${ }^{5}$ $\mathrm{MDA}$ is expressed as nanomoles $\mathrm{MDA} / \mathrm{mg}$ tissue. ${ }^{32}$

\section{Measurement of Antioxidant Enzymes}

Tissue preparation for enzyme assay of rat lung was rapidly thawed from $-70^{\circ} \mathrm{C}$ at room temperature for 5 min and manually homogenised in cold phosphate buffer $(\mathrm{pH}$ 7.4) and debris removed by centrifugation at $3500 \mathrm{~g}$ for $10 \mathrm{~min}$ (Centrifuge $5415 \mathrm{R}$, Eppendorf AG, Hamburg, Germany). Supernatants were recovered and used for enzyme activity and protein assays.

The activity of SOD was measured with SOD detection kit according to the manufacturer's instructions. The SOD activity is then evaluated by the degree of inhibition of this reaction. The level of SOD was measured at $505 \mathrm{~nm}$ and through a standard curve and expressed as $\mathrm{U} / \mathrm{mg}$ protein. ${ }^{5,33}$

The activity of GPx was measured with GPx detection kit according to the manufacturer's instructions. The GPx was evaluated spectrophotometrically against blank at $340 \mathrm{~nm}$. GPx 1 unit was $1 \mathrm{~mol}$ of oxidized NADPH per min per mg of tissue protein. The GPx activity was expressed as $\mathrm{U} / \mathrm{mg}$ protein. ${ }^{5,33}$

\section{Histopathological examination of the lung damage}

The tissue of the lung was fixed in a $10 \%$ neutral buffered formalin solution, embedded in paraffin and used for histopathological examination with hematoxylin and eosin (H and $\mathrm{E})$ stain. $^{5}$

\section{Immunohistochemical Examination of the Expression of Caspase 3}

The paraffin-embedded lung was cut into $4 \mu \mathrm{m}$ sections and mounted on positively charged slides for the expression of caspase-3 immunohistochemistry. ${ }^{11}$ Immunohistochemistry reactions were performed using the peroxidase/anti-peroxidase (PAP) method. Non-specific peroxidase reactions were blocked with methanol containing $0.1 \% \mathrm{H}_{2} \mathrm{O}_{2}$. The sections were also incubated with normal goat serum to avoid nonspecific reactions once the samples were incubated with specific antibodies against caspase-3 (dilution,1:2000, Santa CruzCA, USA). Tissue sections were then washed with phosphate buffer and incubated with secondary antibodies (1:2000; Sigma, USA), before being washed in phosphate buffer again and, finally, incubated with the PAP complex (dilution,1:200). The peroxidase reaction was carried out using a solution of 3,3'-diaminobenzidine tetrahydrochloride containing $0.01 \% \mathrm{H}_{2} \mathrm{O}_{2}$ in Tris- $\mathrm{HCl}$ buffer $(0.05 \mathrm{M}, \mathrm{pH}$ 7.6). After immunostaining, the lung sections were lightly counterstained with hematoxylin and observed under a light microscope.

\section{Statistical Analysis}

Data were presented as means \pm standard deviation. Statistical comparison of biochemical and antioxidant 
enzyme parameters was done using one-way analysis of variance followed by the LSD test using a statistical package program (SPSS V. 17.0). In cases where ANOVA showed significant differences, LSD test was performed. $P<0.05$ was considered to be statistically significant.

\section{RESULTS}

\section{Characterization of Chitosan- Pinus merkusii extract nanoparticles by Scanning Electron Microscopy}

Scanning Electron Microscopy (SEM) images of the chitosan- Pinus merkusii nanoparticles prepared using ionic gelation revealed that the nanoparticle surface showed the rough surface morphology and an irregular shape [Figure 1].

\section{Characterization of Chitosan- Pinus merkusii Nanoparticles by Dynamic Light Scattering}

The average particle size of the Chitosan- Pinus merkusii extract nanoparticles by Dynamic Light Scattering was $430.5 \pm 24.8 \mathrm{~nm}$ as shown in Figure 2.

\section{Effects of Chitosan- Pinus merkusii Extract Nanoparticle on Lead Acetate-Induced Changes in MDA, SOD and GPx of Lung Tissue}

Table 1 showed the results of the level of MDA, SOD and GPx of lung tissue changes in all groups. In the lead acetate group, the level of MDA of lung tissue was significantly increased compared to the control group $(p<0.05)$. Treatment with Chitosan-Pinus merkusii extract nanoparticle at dose $600 \mathrm{mg} / \mathrm{Kg} \mathrm{BW}$ markedly reduced lung tissue MDA in lead acetate treatment which was significantly different from the lead acetate group $(p<0.05)$. Table 1 also showed the results of the lead acetate group, the level of SOD and GPx of lung tissue were significantly decreased compared to the control group $(p<0.05)$. Treatment with Chitosan- Pinus merkusii extract nanoparticle at dose $600 \mathrm{mg} / \mathrm{Kg} \mathrm{BW}$ markedly enhanced lung SOD and GPx which was significantly different from the lead acetate group $(p<0.05)$.

\section{Effects of Chitosan-Pinus merkusii Extract Nanoparticle on the Expression of Caspase 3 of Lead Acetate}

An increase in the expression of caspase 3 indicates lung cell apoptosis. Figure 3 showed the results of the expression of caspase 3 of lung cell apoptosis. In the lead acetate group, the expression of caspase 3 of lung tissue was significantly increased compared to the control group $(p<0.05)$. Treatment with ChitosanPinus merkusii extract nanoparticle at dose $600 \mathrm{mg} / \mathrm{Kg}$
BW markedly reduced lung tissue caspase 3 expression which was significantly different from the lead acetate group $(P<0.05)$.

\section{Effects of Chitosan- Pinus merkusii Extract Nanoparticle on Lead Acetate Induce Lung Cell Damage}

Figures 4 show the histological changes in the lung of control group shows normal architecture with normal appearance of alveolar. In the lead acetate group showed lung cell damage (Thickened the alveolar septa and necrosis). In the rats, treated with Chitosan-Pinus merkusii extract nanoparticle, the number and morphological integrity of lung cells are being preserved. Observations indicate that the lung toxic effects lead acetate was reduced by Chitosan-Pinus merkusii extract nanoparticle [Figure 4].

\section{DISCUSSION}

In the field of medicine, the nanotechnology has developed with various aspects such as drug delivery, tissue engineering for the diagnosis of various diseases. ${ }^{22,23}$ Due to new advances in nanotechnology, it is now pos-

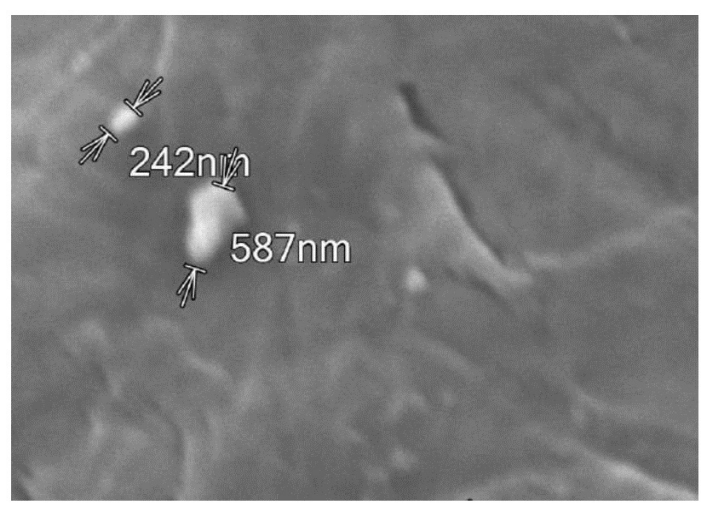

Figure 1: Scanning Electron Microscope Images of ChitosanPinus merkusii Nanoparticles.

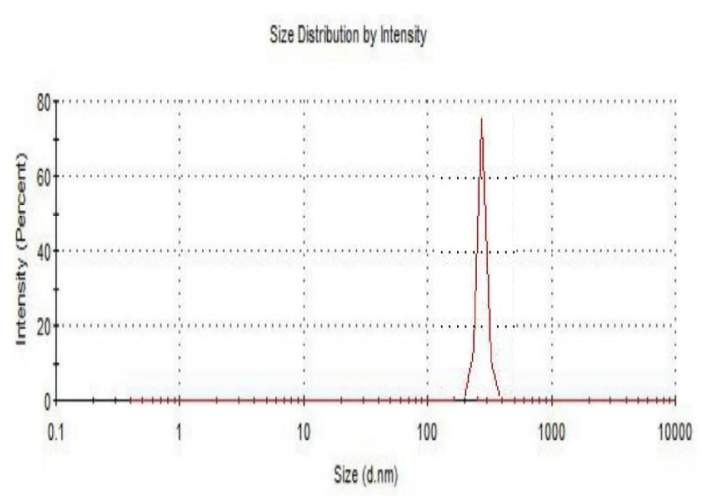

Figure 2: Size Distribution of Chitosan- Pinus merkusii Extract Nanoparticles by Dynamic Light Scattering. 


\begin{tabular}{|c|c|c|c|}
\hline \multirow[t]{2}{*}{ Groups } & \multicolumn{3}{|c|}{ Means SD } \\
\hline & MDA & SOD & GPx \\
\hline & (nmol/mg) & (U/mg) & (U/mg) \\
\hline Control Groups & $2.13^{a} \pm 0.35$ & $8.37^{\mathrm{a}} \pm 0.76$ & $6.98^{\mathrm{a}} \pm 0.71$ \\
\hline Lead Acetate Groups & $3.94^{b} \pm 0.32$ & $4.91^{\mathrm{b}} \pm 0.57$ & $4.23^{\mathrm{b}} \pm 0.62$ \\
\hline Chitosan- P. merkusii 150 mg/kg BW & $4.12^{b} \pm 0.97$ & $4.67^{b} \pm 0.48$ & $4.47^{b} \pm 0.68$ \\
\hline Chitosan- P. merkusii 300 mg/kg BW & $3.86^{b} \pm 0.51$ & $5.72^{\mathrm{b}} \pm 0.83$ & $4.62^{\mathrm{b}} \pm 0.43$ \\
\hline Chitosan- P. merkusii 600 mg/kg BW & $3.01^{c} \pm 0.43$ & $6.42^{\mathrm{c}} \pm 0.65$ & $5.37^{c} \pm 0.41$ \\
\hline
\end{tabular}

$a, b, c$ Different superscript within each column indicate significant difference between the means $(p<0.05)$

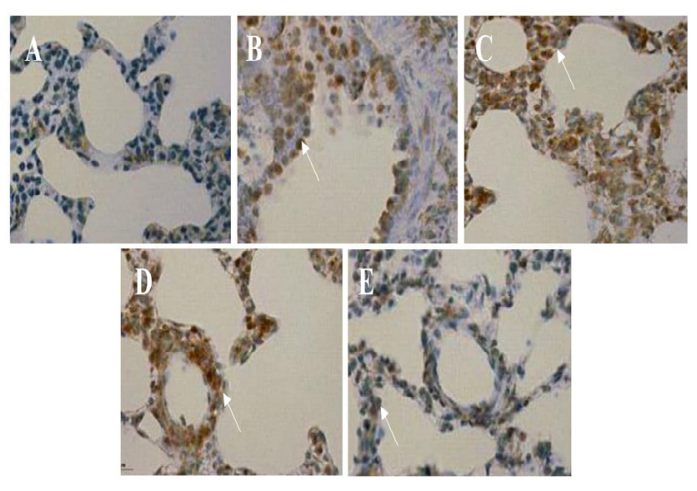

Figure 3: Immunohistochemical study of Chitosan- $P$ merkusii extract nanoparticle on caspase 3 expression of lead acetateinduce lung toxicity. Control group (A); Lead acetate group showed caspase 3 expression of were significantly increased (B); Dose dependent-manner of Chitosan- Pinus merkusii extract nanoparticle $150 \mathrm{mg} / \mathrm{kg} \mathrm{BW} ; 300 \mathrm{mg} / \mathrm{kg} \mathrm{BW}$ and $600 \mathrm{mg} /$ kg (C; $D$ and $E)$ decreased lung tissue caspase 3 expression.

sible to produce natural product nanoparticles that can be utilized in a variety of innovative ways. Nanoparticlebased natural product delivery systems offer enhanced drug stability, treatment efficacy and penetration power compared to a pure natural product. ${ }^{23}$

The variety of polymers that were used for herbal extract-loaded nanoparticles, however chitosan has received great attention in both the medical and pharmaceutical fields. ${ }^{23}$ Chitosan, a biodegradable and biocompatible polymer, is a modified natural carbohydrate and the second most abundant polysaccharide in nature..$^{25,27}$ We made Pinus merkusii extract was encapsulated into chitosan nanoparticle with use sodium tripolyphosphate on ionotropic gelation method, which has more advantages over Pinus merkusii extract. Due to this modification can improve biodistribution and increase specificity and sensitivity and reduced pharmacological toxicity. ${ }^{26,27}$ The results of the DLS showed that the size of Chitosan-Pinus merkusii extract nanoparticle was $430.5 \pm 24.8$ $\mathrm{nm}$. The SEM images of the Chitosan-Pinus merkusii

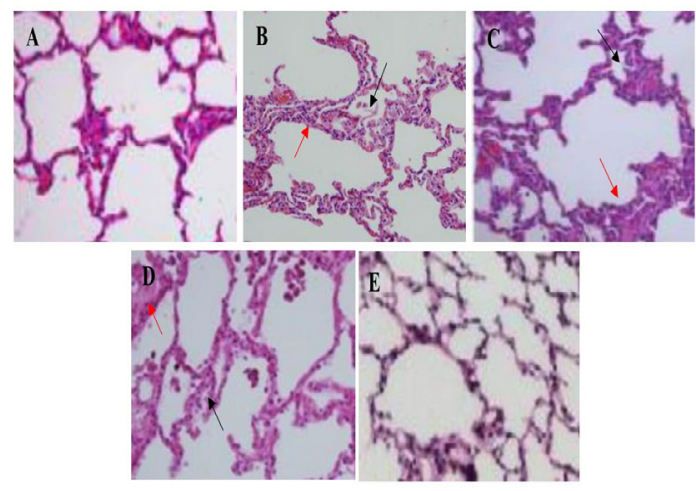

Figure 4: Normal Lung in Control Group (A); The lead acetate treated group shown thickened the alveolar septa (red arrows) and necrosis (black arrows) as compared to the control group (B); Treated with Chitosan- Pinus merkusii extract nanoparticle $150 \mathrm{mg} / \mathrm{kg} \mathrm{BW,} 300 \mathrm{mg} / \mathrm{kg}$ BW showed like a lead acetate treated group (C, D); and Treated with $600 \mathrm{mg} / \mathrm{kg}$ showed regeneration in lung cells $(E)$, using haematoxyline and eosin stain technique $(\times 400)$.

extract nanoparticles showed an irregular shape and the morphology surface showed the rough surface. In our study, administration of lead acetate significant increase MDA level, as a product of lipid peroxidation and showing oxidative damage to the lung. The various toxic effects induced by lead acetate in biological systems have been linked to increased MDA or lipid peroxidation. ${ }^{3,7}$ The present investigation resulted in significantly increased MDA levels in the lung of lead acetate treated rat in comparison to the control group. This means that it increased the oxidative stress in the lead acetatetreated rats. It is known that lead acetate induced oxidative stress and tissue damage could be caused by two mechanisms including increased generation of Reactive Oxygen Species (ROS) and by causing direct depletion of antioxidant reserves. ${ }^{7}$ The lipid peroxidation can be increased by lead acetate administration, which may affect the cytoplasmic membranes and mitochondrial, causing more severe oxidative damage in the tissues and consequently releasing lipid hydroperoxides into circula- 
tion which reflects the induction of oxidative stress. ${ }^{1,2}$ In this study, Chitosan- Pinus merkusii extract nanoparticle, which behaves as a powerful antioxidant and free radical scavenger, can decrease the MDA level perturbed by lead acetate in rats lung. Treatment of rats with Chitosan- Pinus merkusii extract nanoparticle at a dose of $600 \mathrm{mg} / \mathrm{kg} \mathrm{BW}$ prevented the levels of MDA to rise when the rats were challenged with lead acetate. This means that Chitosan- Pinus merkusii extract nanoparticle minimized the toxic effect of lead acetate via its antioxidant activity. The antioxidant protective mechanism decreases the oxidative stress and scavenges the free radical responsible for the lung damage and thus inhibit the lipid peroxidation as measured by MDA levels. The findings of this study suggest that Chitosan- Pinus merkusii extract nanoparticle could attenuate oxidative stress by decreasing the lipid peroxidation (MDA level) in the lead-treated lung.

The activities of SOD and GPx have been used to assess oxidative stress in cells. Many studies have shown that lead acetate has a high affinity for SH groups in several enzymes such as SOD and GPx, thus it can alter antioxidant activities by inhibiting functional $\mathrm{SH}$ groups in these enzymes. ${ }^{1,2,5}$ In the present study, the activity of SOD and GPx in rat lung was decreased by lead acetate treatment. This decreased SOD and GPx activities with lead acetate treatment is in agreement with previous studies. This showed that lead acetate-induced oxidative stress by inhibiting the activity of this antioxidant enzyme. Interestingly, the administration of ChitosanPinus merkusii extract nanoparticle increased the activities of SOD and GPx in the lung of lead-treated rats, which might be due to the ability of Chitosan- Pinus merkusii extract nanoparticle to reduce the accumulation of free radicals. Chitosan- Pinus merkusii extract nanoparticle acts as a scavenger for the oxygen-derived free radicals, thus protecting from lung damage. The decrease in lipid peroxidation due to Chitosan- Pinus merkusii extract nanoparticle has been attributed to alterations in the antioxidant defense system which includes enzymes such as SOD and GPx, which normally protect against free radical toxicity. The mechanism of action of Chitosan- Pinus merkusii extract nanoparticle also may involve the scavenging of free radicals which can inhibit free radical formation.

It has been reported that the lead toxicity condition can cause excessive production of ROS, there is an imbalance between the production of oxidants and the defense systems of antioxidant which may promote the induction of lipid peroxidation, proteins and DNA damage, leading to lung cell death via apoptosis or necrosis., ${ }^{9,12}$ Expression of the caspase- 3 is a hallmark of apoptosis and can be used in cellular assays to quantify activators and inhibitors of the "Death cascade". ${ }^{13}$ In this study showed that in the lead acetate group, the expression of caspase 3 of lung tissue was significantly increased compared to the control group. Dose dependent-manner of Chitosan-Pinus merkusii extract nanoparticle decreased lung tissue caspase 3 expression in lead acetate treatment. It has been reported that cell apoptosis induced by lead toxicity was associated with mitochondrial injury and changes in levels of apoptogenic proteins including Bcl-2, Bax and caspase- $3 .{ }^{11}$ In lead toxicity, the expression levels of caspase- 3 and Bax significantly increased, while the levels of Bcl-2 significantly decreased.

The Histopathological results demonstrating structural changes in the lung tissue of heavy metal toxicity such as lead acetate were reported by some researchers. In the present study, histopathological view of lung sections in the lead acetate treated group showed the lung cell damage (Necrosis) as compared to the control group. The lung damage (Necrosis) was considered mild in the groups treated with Chitosan- Pinus merkusii extract nanoparticle.

\section{CONCLUSION}

The results of the present study indicate that lead acetate-induced lung toxicity might be related with both oxidant and caspase 3. The administration of ChitosanPinus merkusii extract nanoparticle lessened the effects of lead acetate-induced lung toxicity possibly by increasing antioxidant and inhibiting caspase 3 expression. Further investigation of these promising protective effects of Chitosan- Pinus merkusii extract nanoparticle against lead acetate-induced lung cell damage may have a considerable impact on developing clinically feasible strategies to treat patients with lead acetate-induced lung toxicity.

\section{ACKNOWLEDGEMENT}

The authors would like to acknowledge the support of Airlangga University, Surabaya, Indonesia in conducting this research work

\section{CONFLICT OF INTEREST}

The authors declare no conflict of interest.

\section{ABBREVIATIONS}

DLS: Dynamic Light Scattering; SEM: Scanning Electron Microscope; MDA: Malondialdehyde; SOD: Superoxide Dismutase; GPx: Glutathione Peroxidase; ROS: Reactive Oxygen Species; BW: Body Weight. 


\section{REFERENCES}

1. Gagan F, Deepesh G, Archana T. Toxicity of lead: A review with recent updates. Interdiscip Toxicol. 2012;5(2):47-58.

2. Hsu PC, Guo YL. Antioxidant nutrients and lead toxicity. Toxicol. 2002;180(1):33-44.

3. Sudjarwo SA, Eraiko K, Wardani GK. Protective effects of piperine on lead acetate induced-nephrotoxicity in rats. Iranian J Basic Med Sci. 2017;20(11):1227-31.

4. Sudjarwo SA, Wardani GK. Protective effect of curcumin on lead acetateinduced testicular toxicity in Wistar rats. Res Pharm Sci. 2017;12(5):381-90.

5. Wardani G, Farida N, Andayani R, Kuntoro M, Sudjarwo SA. The potency of red seaweed (Eucheuma cottonii) extracts as hepatoprotector on lead acetate-induced hepatotoxicity in mice. Phcog Res. 2017;9(3):282-6.

6. Marwa AA, Khaled M, Hassanein A. Cardio protective effects of Nigella sativa oil on lead induced cardio toxicity: Anti inflammatory and antioxidant mechanism. J Physiol Pathophysiol. 2013;4(5):72-80.

7. Samarghandian S, Borji A, Afshari R, Delkhosh MB, Gholami A. The effect of lead acetate on oxidative stress and antioxidant status in rat bronchoalveolar lavage fluid and lung tissue. Toxicol Mech Methods. 2013;23(6):432-6.

8. Rezk RG, Abdel-Rahman NA. Protective effects of lipoic acid against oxidative stress induced by lead acetate and gamma-irradiation in the kidney and lung in albino rats. Arab J Nuc Sci Appl. 2013;46(2):324-37.

9. Ibrahim NM, Eweis EA, El-Beltagi HS, Abdel-Mobdy YE. Effect of lead acetate toxicity on experimental male albino rat. Asian Pac J Trop Biomed. 2012;2(1):41-6.

10. Kaushik A, Husain A, Awasthi H, Singh DP, Khan R, Mani D. Antioxidant and hepatoprotective potential of Swaras and Hima extracts of Tinospora cordifolia and Boerhavia diffusa in Swiss albino mice. Phcog Mag. 2017;13(Suppl 3):S658-62.

11. Jackie T, Haleagrahara N, Chakravarthi S. Antioxidant effects of Etlingera elatior flower extract against lead acetate-Induced perturbations in free radical scavenging enzymes and lipid peroxidation in rats. BMC Res Notes. 2011;4(1):67-71.

12. Xu J, Lian LJ, Wu C, Wang XF, Fu WY, Xu LH. Lead induces oxidative stress, DNA damage and alteration of $\mathrm{p} 53, \mathrm{Bax}$ and $\mathrm{Bcl}-2$ expressions in mice. Food Chem Toxicol. 2008;46(5):1488-94.

13. Yuan G, Dai S,Yin Z, Lu H, Jia R, Xu J. Sub-chronic lead and cadmiumcoinduce apoptosis protein expression in liver and kidney of rats. Int $\mathrm{J}$ Clin Exp Pathol. 2014;7(6):2905-14.

14. Cragg GM, Newman DJ. Natural products: A continuing source of the novel drug. Biochim Biophys Acta. 2013;1830(6):3670-95.

15. Kaushik D, Aggarwal A, Kaushik P, Mehra R, Rana AC. Pinus roxburghiiIncredible Gift in the Lap of Himalayas. Int J Pharmacogn Phytochem Res. 2010;2(2):29-35.

16. Li YY, Feng J, Zhang XL, Cui YY. Pine Bark extracts: Nutraceutical, Pharmacological and Toxicological evaluation. J Pharmacol Exp Ther. 2015;353(1):9-16.
17. Kim NY, Jang MK, Lee DG, Yu KH, Jang HJ, Lee SH. Comparison of methods for proanthocyanidin extraction from pine (Pinus densiflora) needles and biological activities of the extracts. Nutr Res Pract. 2014;4(1):16-22.

18. Ku CS, Mun SP. Characterization of proanthocyanidin in hot water extracts isolated from Pinus radiata bark. Wood Sci Technol. 2007;41(3):235-47.

19. Ince I, Yesil-Celiktas O, Karabay-Yavasoglu NU, Elgin G. Effects of Pinus brutia bark extract and pycnogenol in a rat model of carrageenan induced inflammation. Phytomed. 2009;16(12):1101-4.

20. Park IJ, Cha SY, Kang M, So YS, Mun SP, Ryu KS, et al. Effect of proanthocyanidin-rich extract from Pinus radiata bark on the immune response of specific-pathogen-free white leghorn chickens. Poultry Sci. 2011;90(5):977-82.

21. Qadir M, Shah WA. GC-MS Analysis, antibacterial, antioxidant and anticancer activity of essential oil of Pinus roxburghii from Kashmir India. Inter J Res Pharm Chem. 2014;4(1):228-32.

22. Saini R, Saini S, Sharma S. Nanotechnology: The Future Medicine. J Cutan Aesthet Surg. 2010;3(1):32-3.

23. Kumari A, Kumar V. Nanotechnology: a tool to enhance therapeutic values of natural plant products. Trends Med Res. 2012;7(2): 34-42.

24. Ahmed TA, Aljaeid BM. Preparation, characterization and potential application of chitosan, chitosan derivatives and chitosan metal nanoparticles in pharmaceutical drug delivery. Drug Des Dev Ther. 2016;10:483-507.

25. Ghadi A, Mahjoub S, Tabandeh F, Talebnia F. Synthesis and optimization of Chitosan nanoparticles: Potential applications in nanomedicine and biomedical engineering Iran. Caspian J Intern Med. 2014;5(3):156-61.

26. Khanmohammadi M, Elmizadeh H, Ghasemi K. Investigation of size and morphology of chitosan nanoparticles used in drug delivery system employing chemometric technique. Iran J Pharm Res. 2015;14(3):665-75.

27. Sudheesh K, Mishra AK, Arotiba OA, Mamba BB. Chitosan-based nanomaterials: A state-of-the-art review. Int J Biol Macromol. 2013;59:46-58.

28. Wardani G, Mahmiah, Sudjarwo SA. In vitro antibacterial activity of chitosan nanoparticles against Mycobacterium tuberculosis. Pharmacog J. 2018;10(1):162-6.

29. Friedman M, Juneja VK. Review of antimicrobial and antioxidative activities of chitosans in food. J Food Prot. 2010;73(9):1737-61.

30. Vimal S, Majeed SA, Taju G, Farook MA, Rajkumar T, Gopinath D. Chitosan tripolyphosphate (CS/TPP) nanoparticles: Preparation, characterization and application for gene delivery in shrimp. Acta Tropica. 2013;128(3):486-93.

31. Sudjarwo SA, Wardani G, Eraiko K, Koerniasari. The Potency of nanoparticle of Pinus merkusii as immunostimulatory on male wistar albino rat. Int J Nutr Pharmacol Neurol Dis. 2018;8(1):10-5.

32. Ohkawa H, Ohishi N, Yagi K. Assay for lipid peroxides in animal tissues by thiobarbituric acid reaction. Anal Biochem. 1979;95(2):351-61.

33. Weydert CJ, Cullen JJ. Measurement of superoxide dismutase, catalase and glutathione peroxidase in cultured cells and tissue. Nat Protoc. 2010;5(1):5166.

\section{SUMMARY}

- The Dynamic Light Scattering showed that the size of Chitosan- Pinus merkusii extract nanoparticle was $430.5 \pm 24.8 \mathrm{~nm}$.

- Scanning Electron Microscope images of the Chitosan- Pinus merkusii extract nanoparticles showed an irregular shape and the morphology surface showed the rough surface.

- Administration of lead acetate $20 \mathrm{mg} / \mathrm{kg} \mathrm{BW}$ i.p for 7 days resulted in a significant increase in MDA level, caspase 3 expression and lung cell necrosis. Lead acetate also a significant decrease in SOD and GPx.

- Treatment with the Chitosan- Pinus merkusii extract nanoparticle decreased the elevated MDA levels, caspase 3 expression and inhibited lung cell necrosis. The Chitosan- Pinus merkusii extract nanoparticle also significant increase in SOD and GPx.

- This study concluded that Chitosan- Pinus merkusii extract nanoparticle could be a potent natural product provide a promising lung protective effect against lead acetate induced lung toxicity in rats, through increasing antioxidant and inhibiting caspase 3 expression. 


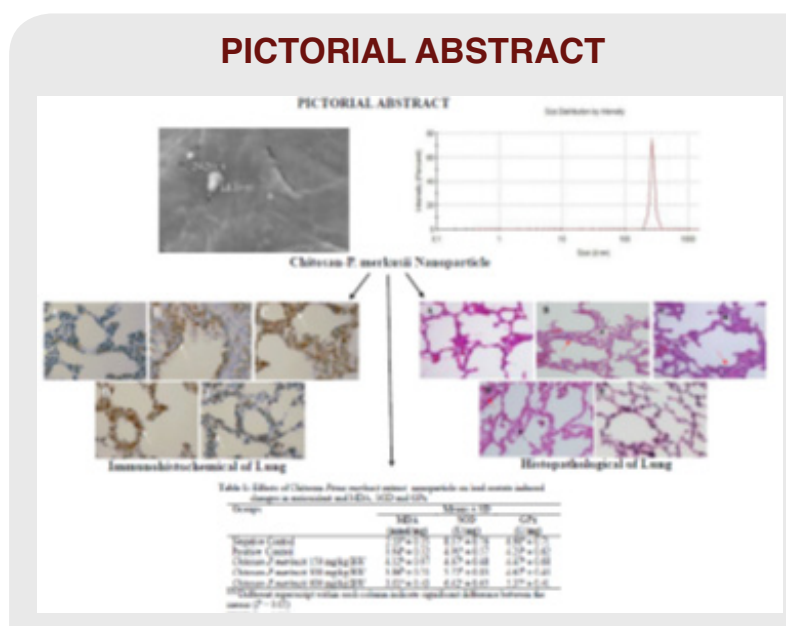

\section{ABOUT AUTHORS}

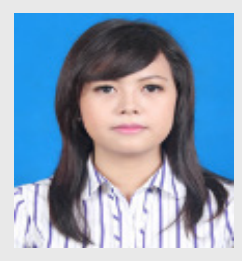

Giftania Wardani: Lecturer at the Department of Pharmacy Biology, Faculty of Pharmacy, Hang Tuah University, Surabaya, Indonesia. where she graduated in Magister Degree at the Department of Molecular Biotechnology, Faculty of Medicine, Konkuk University, Republic of South Korea. Her research focused on Pharmacology and Toxicology.

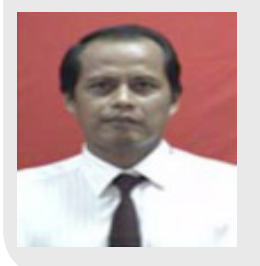

Prof. Sri Agus Sudjarwo, Ph.D: Lecturer at the Department of Pharmacology, Faculty of Veterinary Medicine, Airlangga University, Surabaya, Indonesia, where he graduated in Doctoral Degree at the Department of Pharmacology, Faculty of Agriculture, Tokyo University, Japan. His research focused on Pharmacology and Toxicology.

Cite this article: Sudjarwo SA, Wardani G, Eraiko K, Koerniasari, Ernawati. The Effectiveness of Chitosan- Pinus merkusii Extract Nanoparticle as Antioxidant and Anti-caspase 3 in against Lead Acetate Toxicity on the Lung of Wistar Rat. Indian J of Pharmaceutical Education and Research. 2019;53(2S):s135-s142. 